\title{
Use of Fenton's Reagent for Removal of Organics from Ibn Al- Atheer Hospital Wastewater in Mosul City
}

\author{
Dr. A. F. Q. Al-Harbawi, M. H. Mohammed N. A. Yakoob \\ Lecturer \\ Lecturer \\ Assist. Lecturer \\ University of Mosul - College of Engineering- Environmental Department
}

\begin{abstract}
:
An experiment study on removal of organics by using Fenton's reagents has been introduced. The effect of operating conditions such as $\mathrm{pH}$, reaction time, $\mathrm{H}_{2} \mathrm{O}_{2}$ to $\mathrm{Fe}$ (II) ratio $(\mathrm{W} / \mathrm{W})$, on the efficiency of Fenton process was investigated. The monitored sample taken from wastewater of Ibn Al-Atheer Hospital in Mosul city, has its concentrations of $\mathrm{COD}$ and $\mathrm{BOD}_{5}$, about 663 and $150 \mathrm{mg} / \mathrm{l}$ respectively. The oxidation of organic materials in the wastewater is $\mathrm{pH}$ dependent and the optimum $\mathrm{pH}$ was 3.0. The favorable $\mathrm{H}_{2} \mathrm{O}_{2}: \mathrm{Fe}$ (II) ratio was 1.2:1, and the COD removal rate increased with the increase of Fenton dosage at the favorable $\mathrm{H}_{2} \mathrm{O}_{2}: \mathrm{Fe}$ (II) ratio. The removal efficiency of COD became $93 \%$ and improved the biodegradability of wastewater from 0.226 of influent to 0.618 of effluent.

Keywords: Fenton, hospital wastewater, organic materials.

$$
\begin{aligned}
& \text { استخدام طريقة فينتون في ازالة المواد العضوية لمياه فضلات مستشفى ابن الاثير في } \\
& \text { الموصل } \\
& \text { د. انس فخري قاصد }
\end{aligned}
$$

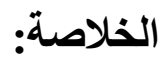




\section{Introduction:}

Hospitals consume an important volume of water a day. Indeed the consumption of domestic water, is on average 100 liters/person/day, while the value generally admitted for hospitals varies from 400 to 1200 liters/day/bed [1]. In hospitals water consumed by various parts such as hospitalization, surgery rooms, laboratories, administrative units, laundry, health services, kitchen and etc, physical chemical and biological quality decreased and converted to wastewater[2]. This important consumption in water of hospitals gives significant volumes of wastewater loaded with microorganisms, heavy metals, toxic chemicals, and radioactive elements [1]. in Mosul city hospitals spread and most of them poor to efficient plants for treatment of wastewater, The fate of this wastewater go to the river which the city depend on it as the a source for living purpose and other process . One of these hospitals is Ibn Al-Atheer that lie on the east of Tiger river, The idea of this research was using Fenton method, it is simple and quickly chemical method for wastewater treatment in this hospital.

The biological treatment technologies, including anaerobic and aerobic processes, have been shown to be effective in treating wastewater, which has a high $\mathrm{BOD}_{5} / \mathrm{COD}$ ratio. The biological technologies may become ineffective for treating wastewater, which has a low $\mathrm{BOD}_{5} / \mathrm{COD}$ ratio. To treat non-biodegradable wastewater, many physical/chemical and biophysical processes have been used [3, 4].

In Fenton process, iron and hydrogen peroxide are two major chemicals determining operation costs as well as efficiency. The Fenton reaction has a short reaction time among all advanced oxidation processes and it has other important advantages. Iron and $\mathrm{H}_{2} \mathrm{O}_{2}$ are cheap and non-toxic, there is no mass transfer limitation due to its homogenous catalytic nature, there is no energy involved as catalyst and the process is easily to run and control. It has been widely used for treatment of highly polluted textile and paper mill wastewaters, as well as pharmaceutical wastewaters [5].

Fenton's reaction is one of the most effective methods of oxidation of organic pollutants that are oxidatively degraded by hydroxyl radicals generated from $\mathrm{H}_{2} \mathrm{O}_{2}$ in the presence of $\mathrm{Fe}^{2+}$ as a catalyst [6].

Fenton's reagent $\left(\mathrm{Fe}^{2+} / \mathrm{H}_{2} \mathrm{O}_{2}\right)$ has been widely applied as an advanced oxidation process for Wastewater treatment. Fenton oxidation process is possessed of advantages of both oxidation and coagulation. Some recent researches had demonstrated that the oxidation mechanism by Fenton's reagent was due to the reactive hydroxyl radical generated in an acidic solution by the catalytic decomposition of hydrogen peroxide [7].

Fenton's Reagent is a mixture of hydrogen peroxide $\left(\mathrm{H}_{2} \mathrm{O}_{2}\right)$ and ferrous iron that reacts to form hydroxyl radicals $\left(\mathrm{HO}^{\circ}\right)$, ferric iron $\left(\mathrm{Fe}^{3+}\right)$, hydroperoxyl radicals $\left(\mathrm{HO}_{2}{ }^{\circ}\right)$ and/or superoxide radicals $\left(\mathrm{O}^{2-}\right)$, according to the following reactions $[8,9,10]$ :

$$
\begin{aligned}
& \mathrm{Fe}^{2+}+\mathrm{H}_{2} \mathrm{O}_{2} \rightarrow \mathrm{Fe}^{3+}+\mathrm{HO}^{-}+\mathrm{HO}^{\circ} \\
& \mathrm{HO}^{\circ}+\mathrm{H}_{2} \mathrm{O}_{2} \rightarrow \mathrm{H}_{2} \mathrm{O}+\mathrm{HO}_{2}{ }^{-} \\
& \mathrm{HO}_{2}{ }^{\circ} \rightarrow \mathrm{O}^{2-}+\mathrm{H}^{+} \quad \mathrm{pKa}=4.8
\end{aligned}
$$

Fenton reaction can be divided into two processes. The first process is an initial oxidation at low $\mathrm{pH}$ of about 3 . The second process which follows the oxidation process is coagulation at high $\mathrm{pH}$ of (7-8) [11].

Many successful applications of Fenton's reagent in wastewater treatment have been reported. Ruangrat K.and Nattapol S.[12] have searched about the evaluation of biodegradability and oxidation degree of hospital wastewater using photo-Fenton process as 
the pretreatment method the wastewater used in their study has its concentration of COD and BOD were $1350 \mathrm{mg} / \mathrm{l}$ and $410 \mathrm{mg} / \mathrm{l}$ respectively they were concluded that the photo-Fenton is asuitable pretreatment method in reducing toxicity of pollutants and enhancing biodegradability of hospital wastewater.

M.I.Badawy and M.E.M,Ali [13] were studied feton,s pre-oxidation and coagulation processes for treatment of combind industrial and domestic wastewater, the wastewater has its concentration of COD (1750-3323)mg/l. They were achieved for color removal of wastewater to $100 \%$ and more than $90 \%$ of COD removal.

Kuo [14] has studied the effects of $\mathrm{pH}$, Fenton's reagent amounts and temperature on decolorizing dye wastewater treatment. At the best $\mathrm{pH}$ value less than $\mathrm{pH} 3.5 .90 \%$ of COD removal and above $97 \%$ of decolonization were obtained. Textile wastewater from a large dyeing and finishing mill has been treated with a combination of Fenton's process and chemical coagulation. COD removal by overall processes was up to $80 \%$.

Sedlak and Andren [15] found that the highest yield in the oxidation of chlorobenzene was in the $\mathrm{pH}$ range of 2-3 and the complexes of compounds with iron might play a role in regulating reaction.

Lou and Lee [16] treated Benzene, Toluene and Xylene (BTX), materials found in contaminated groundwater, using Fenton's reagent. They tested various factors and found some optimum conditions. BTX were effectively oxidized in a period less than ten minutes.

An experiment study on the wastewater treatment with Fenton's Reagent has been implemented in Mosul University to show the effects caused by several different factors and treatment of wastewater by Fenton's process . The experiment results will be introduced and analyzed in this paper.

\section{Materials methods Study Materials}

The wastewater investigated in this experiment was taken from Ibn Al-Atheer hospital in Mosul city. The composition is shown in table 1 .

Table 1 Composition of study wastewater

\begin{tabular}{|c|c|c|}
\hline Parameter & Unit & Value \\
\hline COD & $\mathrm{mg} / \mathrm{l}$ & 663 \\
\hline $\mathrm{BOD}_{5}$ & $\mathrm{mg} / \mathrm{l}$ & 150 \\
\hline $\mathrm{BOD}_{5} / \mathrm{COD}$ & $\mathrm{mg} / \mathrm{l}$ & 0.226 \\
\hline $\mathrm{TSS}$ & $\mathrm{mg} / \mathrm{l}$ & 376 \\
\hline $\mathrm{TDS}$ & $\mathrm{mg} / \mathrm{l}$ & 1552 \\
\hline $\mathrm{VSS}$ & $\mathrm{mg} / \mathrm{l}$ & 382 \\
\hline $\mathrm{pH}$ & & 7.77 \\
\hline $\mathrm{NH}_{3}$ & $\mathrm{mg} / \mathrm{l}$ & 2.364 \\
\hline $\mathrm{NO}_{3}$ & $\mathrm{mg} / \mathrm{l}$ & 1.24 \\
\hline $\mathrm{PO}_{4}$ & $\mathrm{mg} / \mathrm{l}$ & 5.68 \\
\hline $\mathrm{Color}$ & $\%$ & 10 \\
\hline Turbidity & $\mathrm{NTU}$ & 35 \\
\hline
\end{tabular}

From table 1 , wastewater is characterized as low $\mathrm{BOD}_{5} / \mathrm{COD}$ ratio, which can be classified as non-biodegradable wastewater. 


\section{Fenton treatment procedure}

Fenton treatment of wastewater was carried out at ambient temperature in the following sequential steps: (1) wastewater sample was put in a beaker and stirred by mixing machine. its $\mathrm{pH}$ was adjusted to fixed values by $\mathrm{H}_{2} \mathrm{SO}_{4} 98 \%$ (w/w). (2) The scheduled $\mathrm{Fe}^{2+}$ dosage was achieved by adding the necessary amount of solid $\mathrm{FeSO}_{4} \cdot 7 \mathrm{H}_{2} \mathrm{O}$. (3) A known volume of $35 \%(\mathrm{w} / \mathrm{w}) \mathrm{H}_{2} \mathrm{O}_{2}$ solution was added in a single step. (4) After fixed reaction time, before carrying out COD tests, $\mathrm{pH}$ value should be adjusted into 8.0 to remove residual $\mathrm{Fe}^{2+}\left(\mathrm{Fe}^{3+}\right)$. (5) Settlement was achieved for 30 minutes, and then examination of COD should be done.

\section{Results and Discussion}

Results of the experiments should be introduced firstly as shown in table 2 . In this study, we evaluated the efficiency of Fenton process in terms of COD to study the effect of $\mathrm{pH}$, reaction time, $\mathrm{H}_{2} \mathrm{O}_{2}$ : $\mathrm{Fe}(\mathrm{II})$ dosage. COD test is based on the assumption that all the organic materials can be oxidized by the strong oxidizing agent under acidic conditions.

Table 2: The optimum factors for treatment of wastewater by Fenton process

\begin{tabular}{|c|c|c|c|}
\hline Factor & $\mathrm{pH}$ & Reaction time & $\mathrm{H}_{2} \mathrm{O}_{2}: \mathrm{Fe}$ (II) ratio \\
\hline value & 3.0 & $90 \mathrm{~min}$. & $1.2: 1.0$ \\
\hline
\end{tabular}

\section{Effect of pH value:}

The $\mathrm{pH}$ value can affect the reaction of oxidation and coagulation in Fenton process. The experiment was conducted under the conditions of Reaction time $=1 \mathrm{~h}, \mathrm{H}_{2} \mathrm{O}_{2} / \mathrm{FeSO}_{4}=1: 1$, and different $\mathrm{pH}$-values. Fig. 1 shows that residual COD concentration varies with $\mathrm{pH}$ value of the solution. Low $\mathrm{pH}$ has been found effective for Fenton's reagent, and the best removal efficiency is obtained at a $\mathrm{pH}=3$.

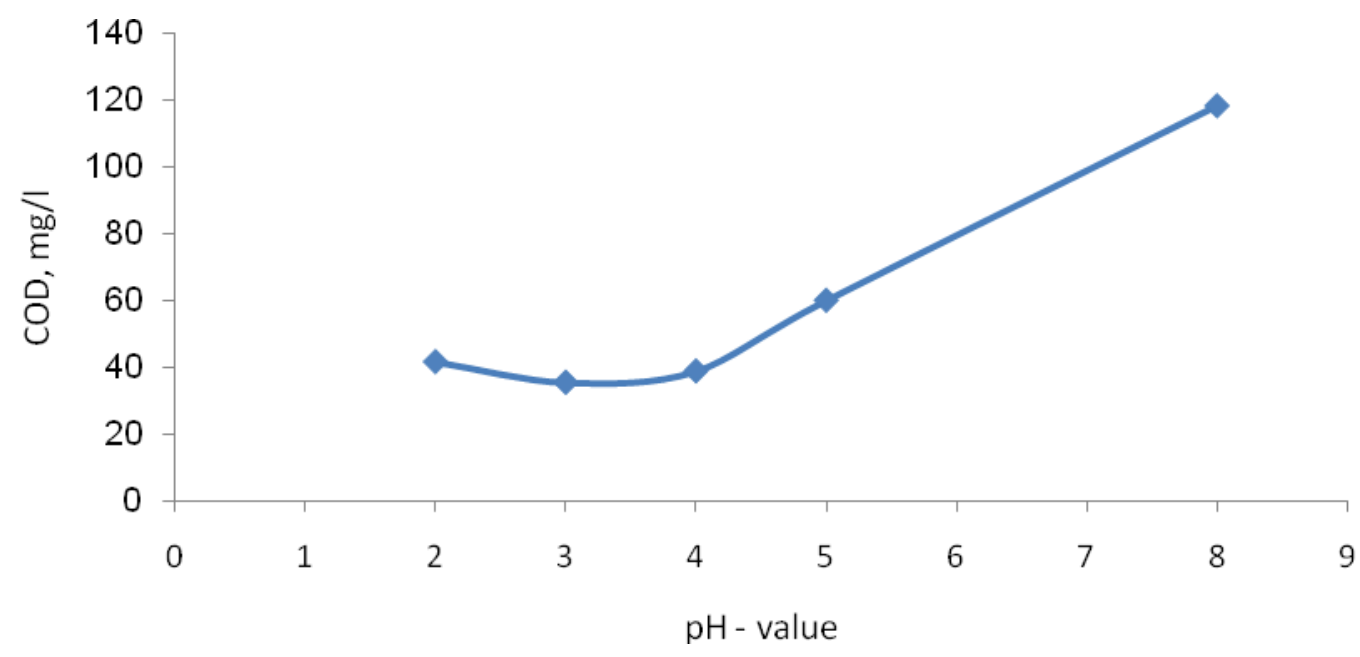

Fig.1: Effect of $\mathrm{pH}$ on the COD removal by Fenton $\left(\mathrm{H}_{2} \mathrm{O} 2=2000 \mathrm{mg} / 1, \mathrm{Fe}^{2+}=2000 \mathrm{mg} / \mathrm{l}\right.$, Reaction time $\left.=90 \mathrm{~min}\right)$

The lower $\mathrm{pH}$ value (3.0) is better to remove inorganic carbons from wastewater because they can scavenge hydroxyl radicals. Inorganic carbons can be easily removed by controlling the $\mathrm{pH}$ to the acidic condition [17]. 


\section{Effect of Reaction Time:}

The optimum reaction time is $90 \mathrm{~min}$. as shown in Fig.2, the results demonstrated that COD decreased gradually to $90 \mathrm{~min}$. reaction time and then increased; this means that the reaction between ferrous iron and hydrogen peroxide with the production of hydroxyl radical was almost complete in $90 \mathrm{~min}$.

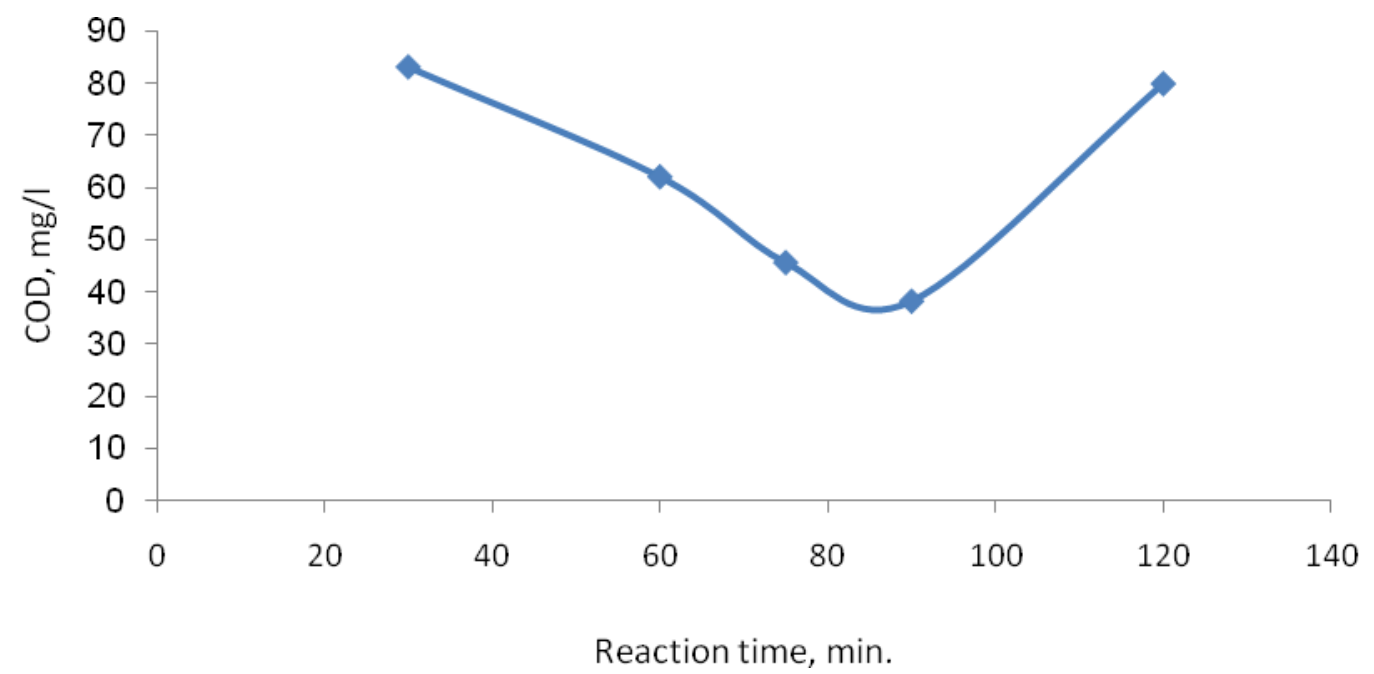

Fig.2: Effect of reaction time on the COD removal $\left(\mathrm{PH}=3.0, \mathrm{H}_{2} \mathrm{O} 2=2000 \mathrm{mg} / 1, \mathrm{Fe}^{2+}=2000 \mathrm{mg} / \mathrm{l}\right)$

\section{Effect of $\mathrm{Fe}^{2+}$ and $\mathrm{H}_{2} \mathrm{O}_{2}$ addition:}

Fenton process, iron and hydrogen peroxide are two major chemicals determining operation costs as well as efficiency. Determination of the favorable amount of Fenton's reagent is highly important. $\mathrm{H}_{2} \mathrm{O}_{2}$ dosage depends on initial COD. A high initial COD generally requires more $\mathrm{H}_{2} \mathrm{O}_{2}$. To investigate the optimum $\mathrm{H}_{2} \mathrm{O}_{2} / \mathrm{Fe}^{2+}$ molar ratio, we studied the effect of $\mathrm{Fe}^{2+}$ and $\mathrm{H}_{2} \mathrm{O}_{2}$ addition. Fig.3 show that the COD decreased with increase amount of $\mathrm{H}_{2} \mathrm{O}_{2}$ to $700 \mathrm{mg} / \mathrm{l}$ and then increased; the optimum amount of $\mathrm{H}_{2} \mathrm{O}_{2}$ was $700 \mathrm{mg} / \mathrm{l}$,

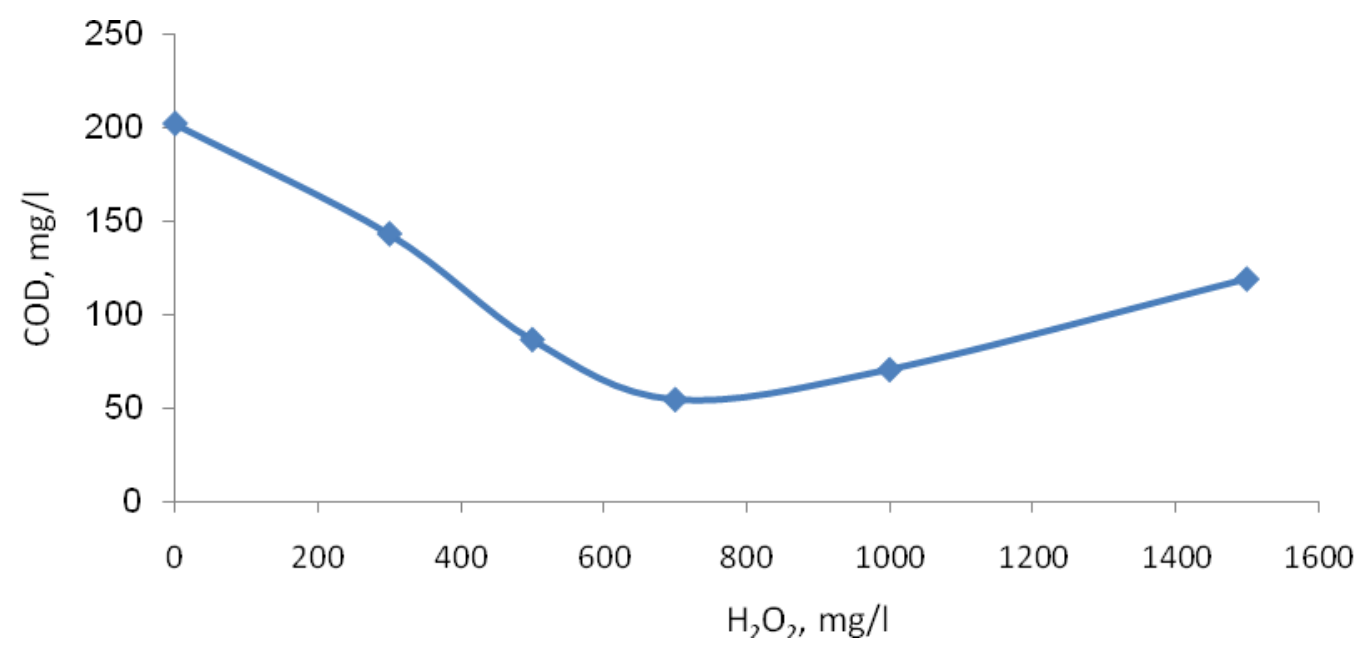

Fig.3: Effect of $\mathrm{H}_{2} \mathrm{O}_{2}$ dosage on the COD removal $\left(\mathrm{PH}=3.0\right.$,reaction time $\left.=90 \mathrm{~min}, \mathrm{Fe}^{2+}=2000 \mathrm{mg} / \mathrm{l}\right)$ 
also increase the amount of $\mathrm{Fe}^{2+}$ lead to decrease COD to $\left(\mathrm{Fe}^{2+}=600 \mathrm{mg} / \mathrm{l}\right)$ and then increased, as shown in Fig.4. From the results above we estimated the optimum $\mathrm{H}_{2} \mathrm{O}_{2} / \mathrm{Fe}^{2+}$ ratio equal to $1.2: 1$. The high concentration of hydrogen peroxide accelerates the Fenton reaction and provides high efficiency in contaminant removal. However, the reaction rate can be inhibited with an excess of hydrogen peroxide, because the excess of $\mathrm{H}_{2} \mathrm{O}_{2}$ will react with 'OH competing with organic pollutants in hospital wastewater and consequently reducing the efficiency of the treatment. [18].

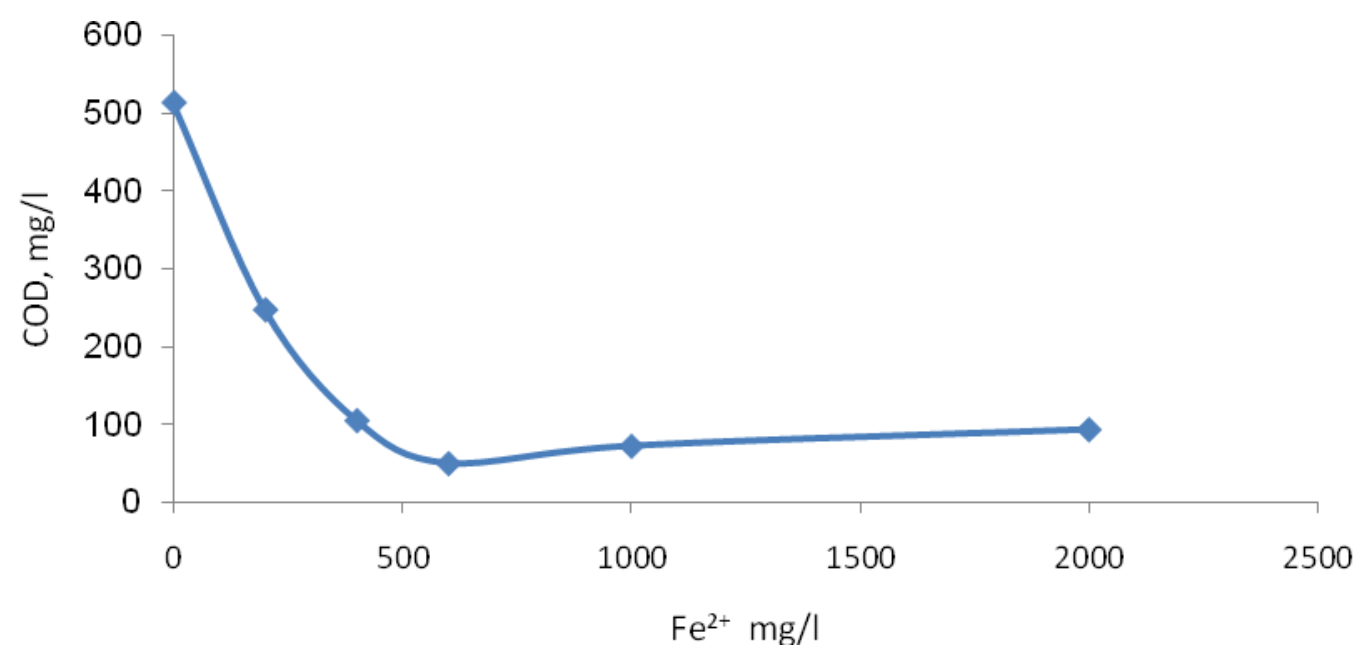

Fig.4: Effect of $\mathrm{Fe}$ (II) dosage on the COD removal $\left(\mathrm{PH}=3.0\right.$, reaction time $=90 \mathrm{~min}, \mathrm{H}_{2} \mathrm{O} 2=2000 \mathrm{mg} / 1$ )

\section{Wastewater treatment by Fenton process:}

Fig.5 and Fig.6 display the COD and $\mathrm{BOD}_{5}$ removal efficiency. The results showed that the wastewater treatment by Fenton process for remove organic matter were $93 \%$ for COD removal and $80 \%$ for BOD. The other characteristics before and after treatment with Fenton are shown in table 3.

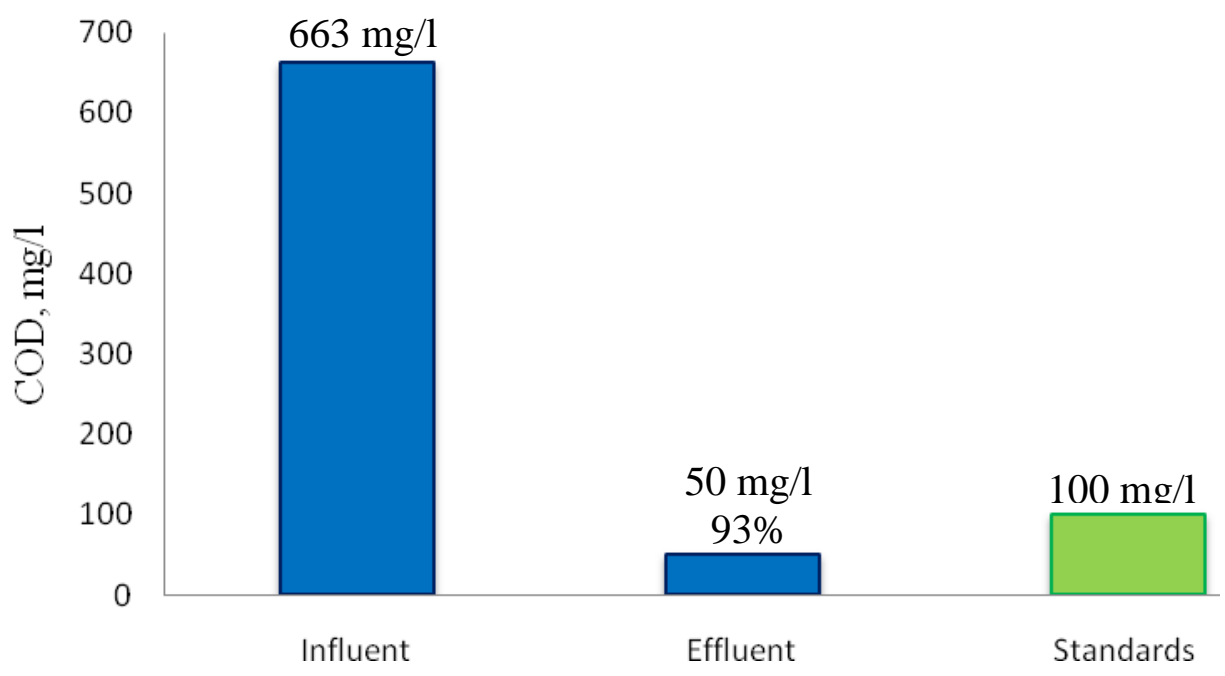

Fig.5: COD removal performance of Fenton method, $\% \mathrm{COD}_{\text {treated }}=\left(\mathrm{COD}_{\text {influent }}{ }^{-}\right.$

$$
\mathrm{COD}_{\text {effluent }} / \mathrm{COD}_{\text {influent }}
$$




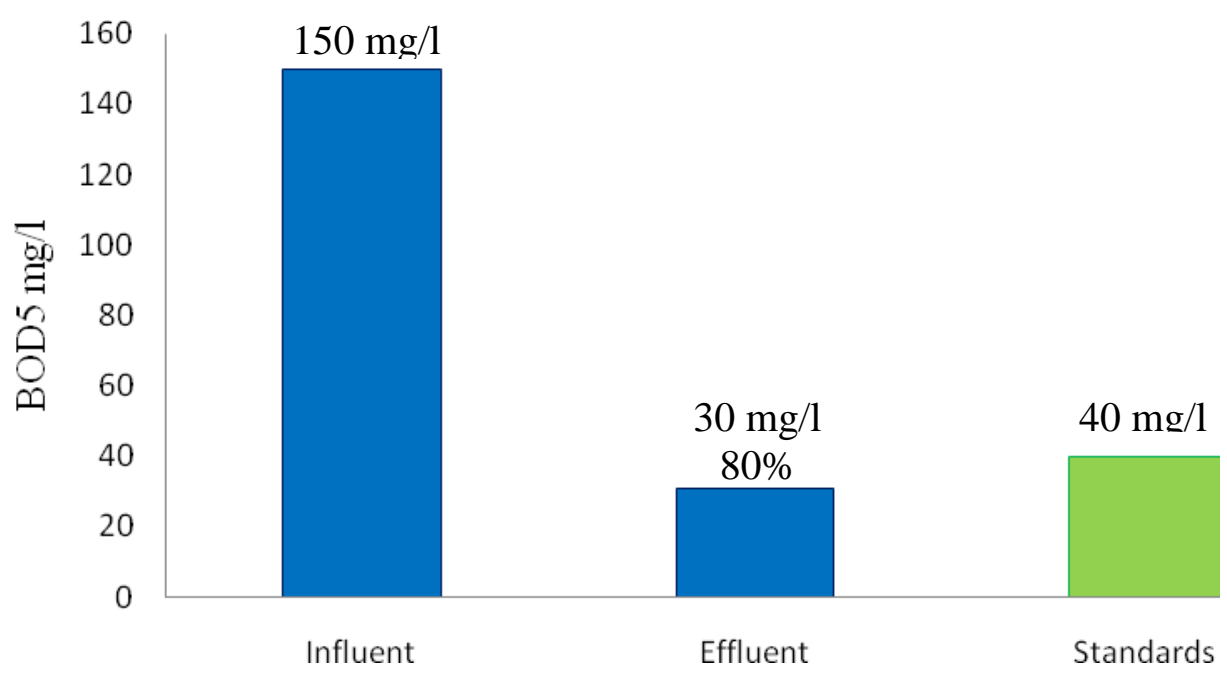

Fig.6 $\mathrm{BOD}_{5}$ removal performance of Fenton method, $\% \mathrm{BOD}_{\text {treated }}=\left(\mathrm{BOD}_{\text {influent }}{ }^{-}\right.$ $\left.\mathrm{BOD}_{\text {effluent }}\right) / \mathrm{BOD}_{\text {influent }}$

Table 3 Characteristics of influent and effluent wastewater

\begin{tabular}{|l|c|c|c|}
\hline \multicolumn{1}{|c|}{ Parameter } & Unit & Value (before treatment) & Value (after treatment) \\
\hline $\mathrm{COD}$ & $\mathrm{mg} / \mathrm{l}$ & 663 & 50 \\
\hline $\mathrm{BOD}_{5}$ & $\mathrm{mg} / \mathrm{l}$ & 150 & 31 \\
\hline $\mathrm{BOD} / \mathrm{COD}$ & $\mathrm{mg} / \mathrm{l}$ & 0.226 & 0.618 \\
\hline $\mathrm{TSS}$ & $\mathrm{mg} / \mathrm{l}$ & 376 & 28.3 \\
\hline $\mathrm{TDS}$ & $\mathrm{mg} / \mathrm{l}$ & 1552 & 620 \\
\hline $\mathrm{VSS}$ & $\mathrm{mg} / \mathrm{l}$ & 382 & 145 \\
\hline $\mathrm{pH}$ & - & 7.77 & 8 \\
\hline $\mathrm{NH}_{3}$ & $\mathrm{mg} / \mathrm{l}$ & 2.364 & 0.657 \\
\hline $\mathrm{NO}_{3}$ & $\mathrm{mg} / \mathrm{l}$ & 1.24 & 0.23 \\
\hline $\mathrm{PO}_{4}$ & $\mathrm{mg} / \mathrm{l}$ & 5.68 & zero \\
\hline Color & $\%$ & 10 & 98 \\
\hline Turbidity & $\mathrm{NTU}$ & 35 & 0.6 \\
\hline
\end{tabular}

\section{Conclusions:}

Fenton treatment is used for removing COD and enhancement of biodegradability of wastewater. Both oxidation and coagulation contributed to COD removal through Fenton treatment of wastewater. Relative contributions depend primarily on $\mathrm{pH}$, molar ratio of Fenton regents.

From the results of the experiments for treating the non-biodegradable wastewater by Fenton's oxidation, the following conclusions can be drawn:

1. The COD removal efficiency by oxidation was affected by the $\mathrm{pH}$ value. The most effective reaction was observed at $(\mathrm{pH}=3.0)$.

2. The reaction time of Fenton process was $90 \mathrm{~min}$. to complete the reaction between ferrous sulfate and hydrogen peroxide.

3. The optimum $\mathrm{H}_{2} \mathrm{O}_{2} / \mathrm{Fe}^{2+}$ (molar ratio) was 1.2:1 according to the results of ferrous sulfate and hydrogen peroxide. 
4. The removal efficiency of COD became $93 \%$ and,

5. Improved the biodegradability of wastewater from 0.226 of influent to 0.618 of effluent wastewater.

\section{References:}

1. Emmanuel E., Perrodin Y., Keck G., Marie Blanchard J., Vermande P.,2002, "Effects of Hospital Wastewater on Aquatic Ecosystem " Congreso Interamericano de Ingeniería Sanitaria y Ambiental Cancún, México, 27 al 31 de octubre,

2. Majlesinasr, M.,1998, "Study of wastewater disposal status and effluent quality in hospitals of Shahid Beheshti University of Medical Sciences". Pejouhandeh., 6: 371375 .

3. Josmaria Lopes de Morais, Patricio Peralta Zamora,2005, "Use of advanced oxidation processes to improve the biodegradability of mature landfill leachates", Journal of Hazardous Materials B123 p.181-186.

4. Kang, Y.W. and K.Y. Hwang,2000, "Effects of reaction conditiom on the oxidation efficiency in the Fenton process", Water Res., 34: 2786-2790.

5. Gotvajn, A.Z. and Z.J. Konean,2005, "Combination of Fenton and Biological Oxidation for Treatment of Heavily Polluted Fermentation Waste Broth Acta Chmica", Slovenica., 52,131-137 Res. Ch., 40: 463-474.

6. Barbusiikkil, K. and K. Filipe,2001, "Use of Fenton's Reagent for Removal of Pesticides from Industrial Wastewater", Polish J. Envlron. Studies, 10: 207-212.

7. Yun Whan Kang and Kyung-Yub Hwang,2000, "Effects of reaction conditions on the oxidation efficiency in the Fenton process", Wat. Res. Vol. 34, No. 10, pp. 2786-2790.

8. Walling, C.W,1975, "Fenton's Reagent Revisited", Accounts of Chemical Research $8: 125-131$.

9. Smith, B.A., R.J. Watts, and D.A. Atkinson,2002, "Destruction of DNAPLs by modified Fenton's Reagent", Platform Abstracts of the Third International Conference on Remediation of Chlorinated and Recalcitrant Compounds, Monterey, Calif., May 20-23.

10. Halliwell, Barry, and J.M.C. Gutteridge,1985, "Free Radicals in Biology and Medicine" Oxford University Press, N.Y.

11. Yoon, J., J.S. Cho and S. Kim,1998, "The characteristics of coagulation of Fenton reaction in the removal of landfill leachate organics", Water Sci. Technol., 38: 209214.

12. Puangrat Kajitvichyanukul, Nattapol Suntronvipart,2006," ," Evaluation of biodegradability and oxidation degree of hospital wastewater using photo-Fenton process as the pretreatment method" Environmental Nanomaterial Research and Development Unit, Department of Environmental Engineering, Faculty of Engineering, King Mongkut's University of Technology Thonburi, 91 Pracha-Utid Road, Tungkru, Bangkok 10140, Thailand Received 16 April 2006; received in revised form 19 May 2006; accepted 22 May 2006 Available online 27 May 2006.

13. M.I. Badawy, M.E.M. Ali,2006," Fenton's peroxidation and coagulation processes for the treatmentof combined industrial and domestic wastewater"

National Research Center, Water Pollution Department, Dokki, Cairo, Egypt

Received 21 September 2005; received in revised form 17 January 2006; accepted 18 January Available online 15 March 2006. 
14. Kuo, W. G.,1992, "Decolorizing Dye Wastewater with Fenton's Reagent." Wat. Res. 26(7), pp. 881.

15. Sedlak, D. L., and Andren, A. W.,1991, "Oxi\&tion of Chlorobenzene with Fenton's Reagent." Environ. Sci. Technol., 25(5), pp. 777-782.

16. Lou, J. C., and Lee, S. S.,1995, "Chemical Oxidation of BTX Using Fenton's Reagent." Hazardour Wmte dl Hazardous Materials, 12(2), pp. 1 85- 193.

17. G.V. Buxton, C.L. Greenstock, W.P. Helman, and A.B. Ross, 1988, "Critical review of rate constants for reaction of hydrated electrons, hydrogen atoms and hydroxyl radicals ( $\mathrm{OH}$ ) in aqueous solution", J. Phys. Chem. Ref. Data 17 ,(pp513-886.

18. D.K. Moon, T. Maruyama, K. Osakada, and T. Yamamoto,1991, "Chemical oxidation of polyaniline by radical generating reagent”, Chem. Lett. (pp.)1633-1636. 